\title{
Statistical analysis of the significance of variation in properties of cotton stalk fibres extracted from different sections of the cotton stalk
}

\author{
Nkosilathi Z Nkomo ${ }^{1 *}$, Londiwe C Nkiwane ${ }^{2}$ \\ ${ }^{1,2}$ Department of Fibre and Polymer Materials Engineering, National University of Science and Technology, \\ P.O Box AC 939, Ascot, Bulawayo, Zimbabwe
}

\begin{abstract}
Cotton is cultivated primarily for its boll fibre and little use is made of the cotton stalk. The cotton stalks are breeding ground for pests therefore the stalks are normally burnt in the field creating air pollution. Cotton stalks were collected from farms through random sampling and subjected to natural water retting and there after mechanical decortication and categorised according to their location relative to the stalk as top section, middle section and bottom section fibres. The physical properties of the cotton stalk fibres was characterised by tensile strength, moisture regain, linear density, diameter and fibre length tests. These results were analysed using one way multivariate analysis (MANOVA) in SPSS with three levels being one for each section of the stalks to test the statistical significance of the differences of the fibre properties from different sections of the cotton stalk. Pillais trace test showed that there was statistical significant difference between fibres from different locations when considered jointly on the variables tensile strength, elongation, fibre density, fibre diameter, fibre length, linear density and moisture regain. This test was followed up by Tuskey's HSD post hoc test which showed which parameters varied between which sections of the stalk.
\end{abstract}

Keywords: - Composites, cotton stalk fibres, fibre properties, multivariate analysis, statistical variation

\section{INTRODUCTION}

Cotton popularly known as "White Gold" is grown for fibre and seed all over the world. Cotton stalks are a by-product of cotton farming with the cotton stalk treated as waste material and small portions of it used as fuel by the rural people and some as animal feed. The cultivation of cotton generates plant residues equivalent to three to five times the weight of fibre produced [1]. These cotton stalks are normally burnt in the field as the preferred disposal method as they tend to harbour several insects and pests which would be harmful to the future croup [2]. The cotton stalks are a potential breeding ground for pests such as pink bollworm and the highly invasive polyphagous cotton mealybug Phenacoccus solenopsis Tinsley (Hemiptera: Pseudococcidae) [3, 4]. These pests feed on the squares or bolls of cotton left over in the cotton stalks for approximately 3 weeks and then commonly enter a state known as diapause which allows it to survive throughout the off season in a dormant state [5].

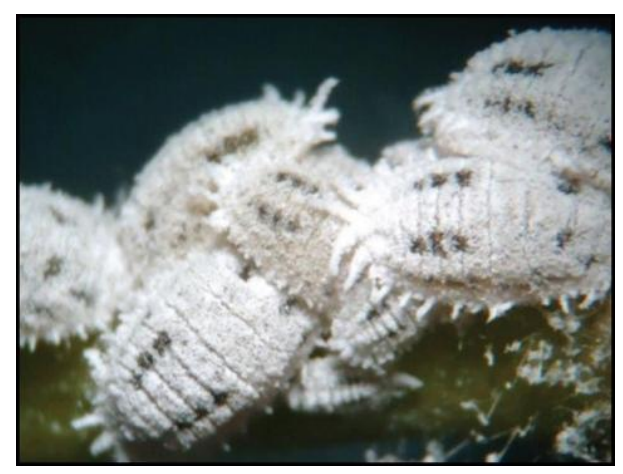

Fig 1.0. Picture of highly destructive, polyphagous mealybug

Burning agricultural residues causes environmental problems such as air pollution, soil erosion and decreases soil biological activity [6]. On average around 0.85 million metric tonnes of $\mathrm{CO}_{2}$ equivalent is released per million tonnes of cotton stalks burnt [7]. Table 1.0 shows a quantification of greenhouse gases emitted per million metric tonnes of cotton stalk burnt in the field. 
Table 1.0. Showing emission of greenhouse gas per million tonnes of cotton stalks burned in the field [8]

\begin{tabular}{|c|c|c|c|}
\hline Green House Gas & Emission Factor $\left(\mathbf{g . k g}^{-\mathbf{1}}\right)$ & Total Emission $(\mathbf{M n}$ & Total Emission (Mn Mt \\
\hline & & MT) & $\left.\mathbf{C o}_{\mathbf{2}} \mathbf{e}\right)$ \\
\hline & & & 0.00265 \\
\hline $\mathbf{N O}_{\mathbf{x}}$ & 2.68 & 0.0027 & 0.7898 \\
\hline $\mathbf{C H}_{\mathbf{4}}$ & 2.7 & & \\
\hline & & & \\
\hline
\end{tabular}

$* \mathrm{NO}-\mathrm{Nitrous}$ oxide, ${ }^{*} \mathrm{CH}_{4}-$ Methane, ${ }^{*} \mathrm{Mn} \mathrm{Mt} \mathrm{Co}_{2} e-$ Million Metric tonnes of carbon dioxide equivalent

Bast fibres are obtained from the stems of various dicotyledonous plants. Botanically the term bast fibre is synonymous with phloem, the food conducting tissue of vascular plants. In bast stems the useful fibres are present as bundles towards the outer area of the stem. For composite reinforcement, the aim is usually to obtain fibres which are 50-100 $\mu \mathrm{m}$ in diameter and can be $100-300 \mathrm{~mm}$ long. These technical fibres are actually themselves bundles of approximately 40 elementary fibres (cells) which may be $10-20 \mu \mathrm{m}$ and 20-50mm long. Bast fibres are found in the outer portion of the stem, with woody core material known as shive [9]. Fig 1.1 shows how a typical cross section of a bast fibre looks like.

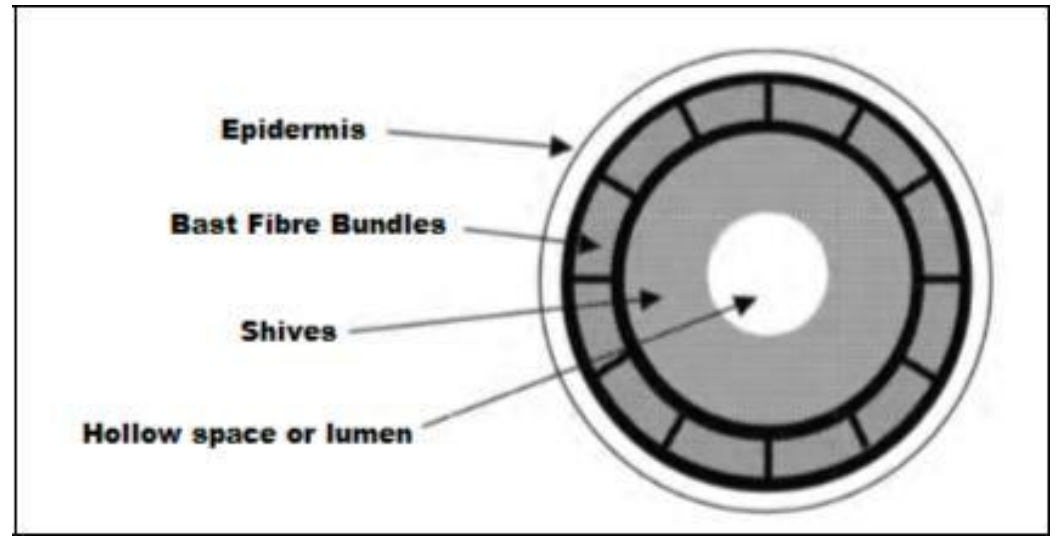

Fig 1.1. Cross section of a bast stem [10]

Bast fibres are normally extracted by retting process and then carrying out mechanical decortication. Most of the natural fibres are relatively cheap to extract and prepare for use. Hence natural fibres have attracted the attention of scientists and engineers for applications in the consumer industry. Most available methods of retting rely on the biological activity of microorganism, bacteria and fungi from the environment to degrade the pectin polysaccharides from the non-tissue and, thereby, separate the fibre bundles. Microbial/enzymatic retting is one of the widely used techniques [11]. The quality of the fibres is largely determined by retting condition and duration. The quality of the water also affects the quality of the fibres. Apparently there is no single method that can give optimum results in terms of retting period, fibre strength, environmental pollution and cost. Table 1.2 shows some of the mechanical properties of common bast fibres. The increasing interest in introducing degradable, renewable, and inexpensive reinforcement materials which are environmentally friendly has stimulated research in the area of bast cellulose fibres. These fibres have the advantage of low cost, less weight and density makes the natural fibres an excellent alternative for synthetic fibres [12].

Table 1.2. Mechanical and physical properties of plant fibres [13]

\begin{tabular}{|c|c|c|c|c|c|c|c|c|}
\hline Fibre & Diameter & Density & $\begin{array}{l}\text { Elongatio } \\
n\end{array}$ & $\begin{array}{r}\text { Lengt } \\
h\end{array}$ & Tensile & $\begin{array}{l}\text { Moistur } \\
e\end{array}$ & Specific & Failure \\
\hline Type & & & & & Strength & regain & Tensile & Strain \\
\hline & & & & & & & Strength & \\
\hline & um & $\mathrm{g} / \mathrm{cm}^{3}$ & $\%$ & $M m$ & $M P a$ & $\%$ & $M P a$ & $\%$ \\
\hline $\begin{array}{l}\text { Bambo } \\
\text { o }\end{array}$ & $10-40$ & - & & 2.7 & 575 & - & 383 & - \\
\hline Flax & $17.8-21.6$ & 1.5 & $2.7-3.2$ & $27.4-36.1$ & \begin{tabular}{|l|}
$500-900$ \\
\end{tabular} & 12.00 & $345-620$ & $1.3-3.3$ \\
\hline Hemp & $17.0-22.8$ & 1.47 & $2-4$ & \begin{tabular}{|l|}
$8.3-14.1$ \\
\end{tabular} & $310-750$ & 12.00 & $210-510$ & $2-4$ \\
\hline Jute & $15.9-20.7$ & 1.3 & $1.5-1.8$ & $1.9-3.2$ & \begin{tabular}{|l|}
$200-450$ \\
\end{tabular} & 17.00 & $\begin{array}{l}140-320 \\
\end{array}$ & $2-3$ \\
\hline Kenaf & $17.7-21.9$ & 1.45 & 1.6 & $2.0-2.7$ & $295-1191$ & 17.00 & - & - \\
\hline
\end{tabular}




\begin{tabular}{|l|l|l|l|l|l|l|l|l|}
\hline Ramie & $28.1-35.0$ & - & $3.6-3.8$ & $60-250$ & 915 & 8.550 & 590 & 3.7 \\
\hline
\end{tabular}

Cotton stalks contain about 33\% fibrous bark layer [14]. The bast fibres extracted from cotton stalk have been shown to be a good reinforcement for polymer composites with mechanical performance similar to that of flax and hemp fibre in fibre reinforced composites [14].

\section{MATERIALS AND METHODS}

The cotton stalks were collected using random sampling technique from cotton farms around Zimbabwe. The collection of the cotton stalks was done immediately after June/July harvest period. Only cotton stalks between 1.0-1.2metres in length were used. The cotton stalks were water retted for a period of 3 weeks in plastic drums using tap water with initial $\mathrm{pH}$ value of 7.40 and conductivity of 204 . The initial TDS value of the retting water was $102 \mathrm{ppm}$. The cotton stalks were weighed down with concrete block to prevent them floating to the surface of the water.

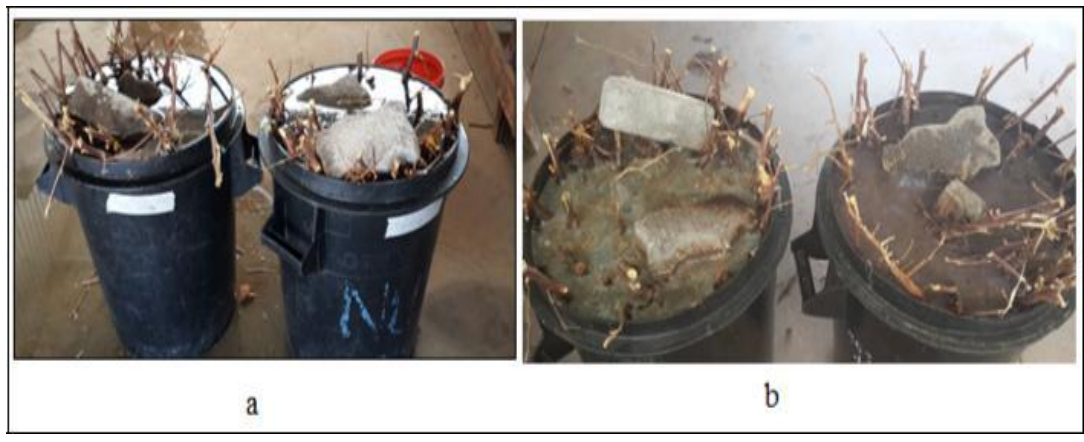

Fig 2.1. Showing natural water retting of cotton stalks at initial (a) and after three weeks (b) After the retting process the cotton stalks were subject to manual decortication using a rubber coated hammer to avoid damage to the cotton stalk fibres as shown in Fig 2.2. There after the cotton stalk fibres were cleaned and combed to remove any adhering dirt particles [15].

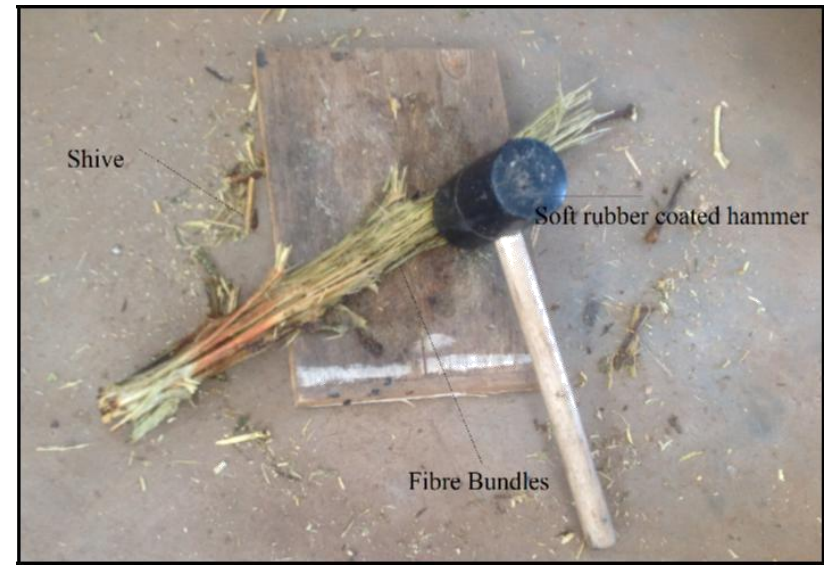

Fig 2.2. Mechanical decortication process in the extraction of cotton stalk fibres [15]

\subsection{Characterization of the cotton stalk fibres}

After extraction the mechanical properties of the cotton stalk fibres were characterised. A number of tests were carried out according to ASTM standards such as fibre length test [16], fibre tenacity test [17], moisture regain test [18], fibre density test and linear density test [19] to determine the mechanical and physical properties of the cotton stalk fibres. The fibres were conditioned under standard atmospheric testing conditions $\left(21 \pm 1^{\circ} \mathrm{C}\right.$ and $65 \pm 2 \%$ relative humidity) for a period of 24 hours prior to testing and characterised according to their origin relative to the cotton stalk. Only stalks between the lengths of $1.0-1.2 \mathrm{~m}$ were used and these were divided into three equal sections which are the top section (TF), middle section (MF) and root section (RF) as shown in figure 2.3 . 


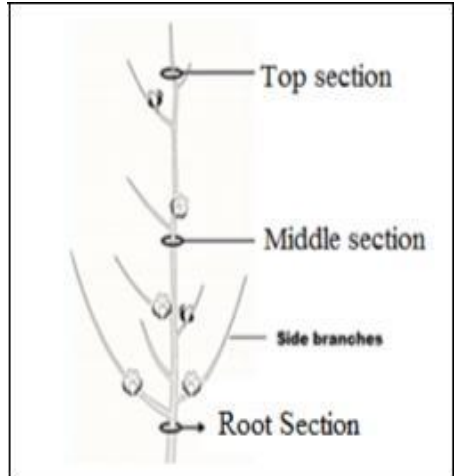

Fig 2.3. Showing the location of extracted fibres on the cotton stalk

\subsection{Statistical Analysis}

MANOVA statistical analysis was carried out using SPSS software to assess the statistical significance in the variation of the fibre mechanical properties from fibres in the different sections of the cotton stalk i.e top section, middle section and root section.

\section{RESULTS AND DISCUSSION}

The cotton stalk fibres extracted were brownish in colour. Generally speaking, extending the water retting duration significantly increased the whiteness of the cotton stalk fibres. Water retting is able to improve the whiteness of fibres because coloured materials and contaminating substances, such as dust, dissolve and settle in the retting water [20]. The fibres from the top section of the stalk were dark brown in colour while the fibresfrom the root section were light brown in colour. Fig 3.1 shows some extracted cotton stalk fibres in a glass beaker.

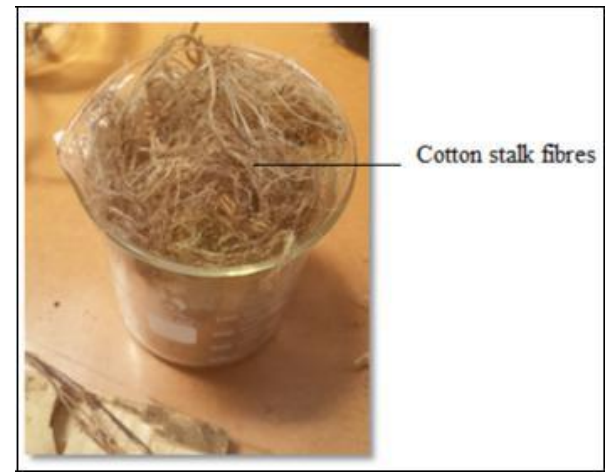

Fig 3.1. Extracted cotton stalk fibres in a beaker

The mechanical properties of the cotton stalk fibre were characterised according to their location on the cotton stalks. The properties of fibres from the different sections were analysed using one way Multi-variance Analysis (MANOVA) on SPSS software to access the significance of the difference in properties between the fibres from different locations of the cotton stalk. The sample size was 40 fibres tested for each of the properties from 3 levels of the cotton stalk which were top section, middle section and root section. Table 3.1 shows descriptive statistics of the mechanical properties of the cotton stalk fibres from the different sections with the standard deviations and mean values.

Table 3.1. Descriptive statistics of the mechanical properties of the cotton stalk fibres

\begin{tabular}{|l|l|r|r|r|}
\hline Parameters & Location on stalk & Mean & $\begin{array}{c}\text { Std. } \\
\text { Deviation }\end{array}$ & N \\
\hline Tensile strength $(\mathrm{MPa})$ & Middle & 56.3 & 0 & 40 \\
\hline & Root & 2.21 & 0 & 40 \\
\hline & Top & 39.79 & 0 & 40 \\
\hline & Total & 32.7667 & 22.72861 & 120 \\
\hline Elongation $(\%)$ & Middle & 0.4734 & 0 & 40 \\
\hline & Root & 0.15 & 0 & 40 \\
\hline
\end{tabular}




\begin{tabular}{|l|l|r|r|r|}
\hline & Top & 0.4103 & 0 & 40 \\
\hline & Total & 0.3446 & 0.14056 & 120 \\
\hline Fibre Density $\left(\mathrm{g} / \mathrm{mm}^{3}\right)$ & Middle & 3.72 & 0 & 40 \\
\hline & Root & 1.45 & 0 & 40 \\
\hline & Top & 5.85 & 0 & 40 \\
\hline & Total & 3.6733 & 1.80413 & 120 \\
\hline Fibre Diameter $(\mathrm{mm})$ & Middle & 0.1835 & 0.01369 & 40 \\
\hline & Root & 0.2275 & 0.03193 & 40 \\
\hline & Top & 0.1538 & 0.03094 & 40 \\
\hline & Total & 0.1882 & 0.04043 & 120 \\
\hline Moisture Regain $(\%)$ & Middle & 10.202 & 0.81965 & 40 \\
\hline & Root & 11.1405 & 0.75181 & 40 \\
\hline & Top & 10.6781 & 1.31388 & 40 \\
\hline & Total & 10.6735 & 1.05793 & 120 \\
\hline Fibre length $(\mathrm{mm})$ & Middle & 7.9012 & 2.94373 & 40 \\
\hline & Root & 6.9162 & 2.01082 & 40 \\
\hline & Top & 9.0488 & 3.46947 & 40 \\
\hline & Total & 7.9554 & 2.97924 & 120 \\
\hline Linear density (tex) & Middle & 3.938 & 0 & 40 \\
\hline & Root & 2.364 & 0 & 40 \\
\hline & Top & 3.683 & 0 & 40 \\
\hline & Total & 3.3283 & 0.69268 & 120 \\
\hline & & & & \\
\hline & & & & \\
\hline
\end{tabular}

The fibres from the root section of the cotton stalks had the lowest strength in comparison to fibre from the top and middle section of the cotton stalk. This could be attributed to the low fibre maturity of the fibres. The fibres from the root section of the cotton stalks had the lowest strength in comparison to fibre from the top and middle section of the cotton stalk. This could be attributed to the low fibre maturity of the fibres. The mean fibre tenacity for fibres from the root section was $0.00533 \mathrm{kgf}$. This gave the fibres a tenacity of $2.21 \mathrm{cN} /$ tex. This tenacity is very low for root section fibres in comparison to other sections of the stalk which had tenacity more than 10times that value. The reason for this is the fibre were over matured and had little strength. The elongation of the root section fibres is calculated as $0.43 \%$. The graph in fig 3.2 shows comparison of the tensile strength of fibres from different sections of the cotton stalk. The root section fibres have the lowest elongation at $0.43 \%$ of all the fibre from different sections of the cotton stalk. The tenacity of the fibres is of importance as it helps determine suitable end use of the fibres. The strength of fibres from the middle and top section which is $56.3 \mathrm{CN} / \mathrm{tex}$ and $39.70 \mathrm{cN} / \mathrm{tex}$ respectively is suitable for use in natural fibre composites this is after looking at properties of other commonly used natural bast fibres such as Jute which has tensile strength of 200-450MPa.

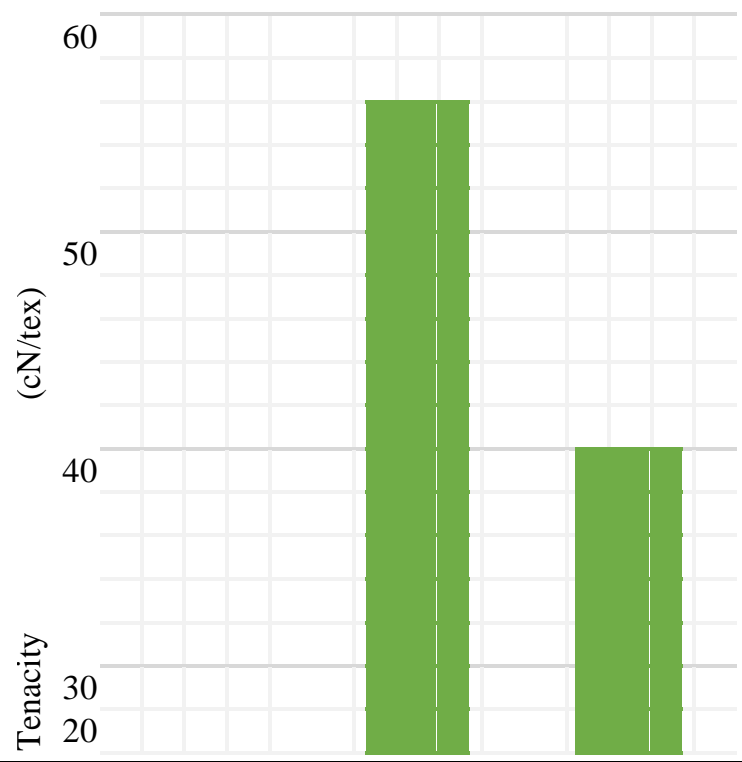




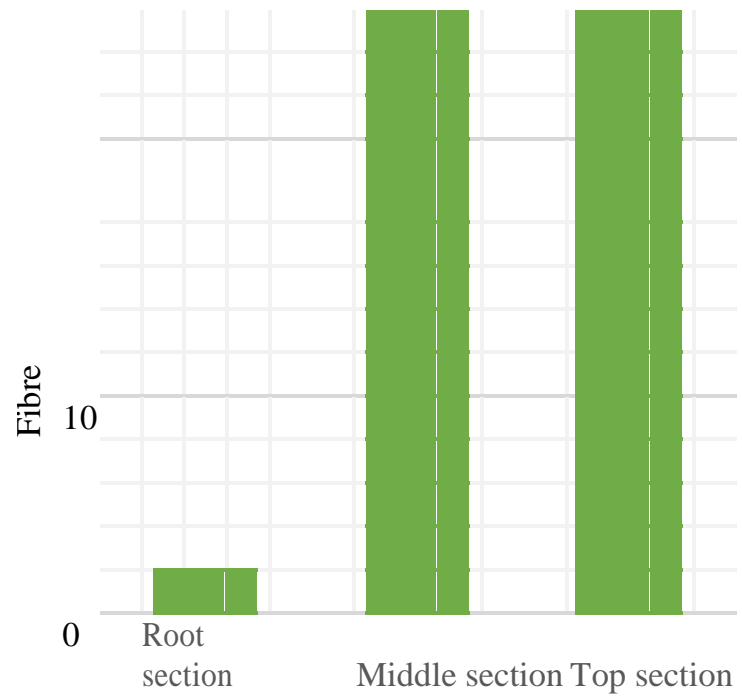

Location of fibres

Fig 3.2. Fibre tenacity results for fibres from different sections of the cotton stalkOne way multi variate analysis test was carried out on the data from the mechanical properties of the cotton stalk fibres. Table 3.2 shows the test results obtained for the MANOVA multivariate test.

Table 3.2. Showing the test results for the multivariate analysis test.

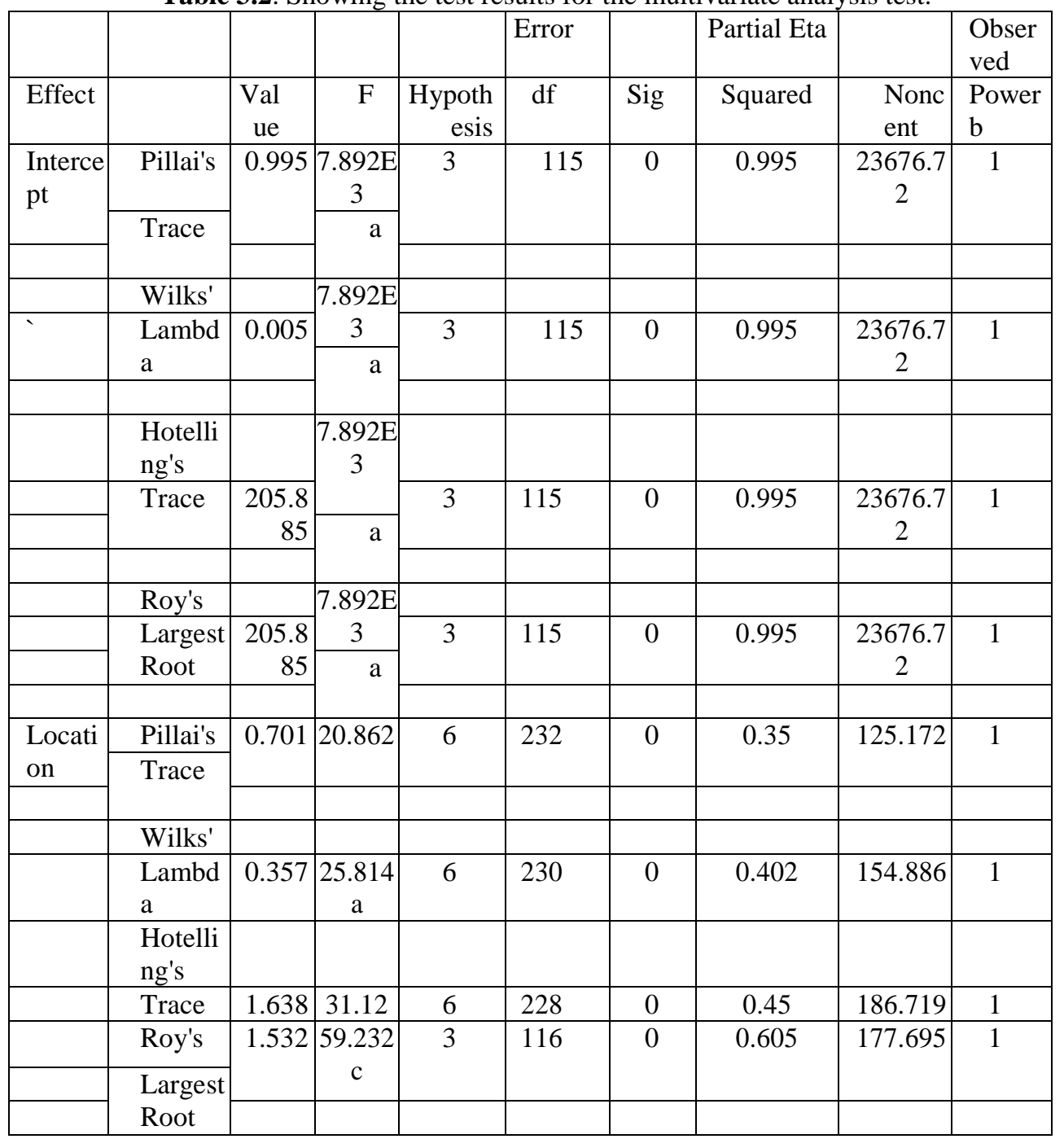




\section{b. The statistic is an upper bound on F that yields a lower bound on the significance level}

\section{Design: Intercept + Location}

From the multivariate tests Pillai's Trace shows there is a significant difference between groups as it is less than the computed alpha of 0.05. There was significant difference between fibres from different location when considered jointly on the variables tensile strength, elongation, fibre density, fibre diameter, fibre length, linear density and moisture regain, Wilk's $A=0.357, F(6,230)=25.81, p<$ 0.0005 , partial $\mathrm{n}^{2}=.402$. We can see from test of between subject effects in Table 3.3 that location has a statistically significant effect on Fibre diameter $\left(\mathrm{F}(2,117)=76.34 ; \mathrm{p}<0.0005 ;\right.$ partial $\mathrm{n}^{2}=0.566$ and Moisture Regain $\left(\mathrm{F}(2,117)=8.917\right.$; $\mathrm{p}<0.0005$; partial $\mathrm{n}^{2}=0.132$ and Fibre length $(\mathrm{F}(2,117)=5.524$; partial $\mathrm{n}^{2}=.086$. A Bonferroni alpha correction was made to account for multiple ANOVAs being run. As such in this case it acceptable that statistical significance at $p<0.025$. The significant ANOVAS can be followed up with Tuskey's HSD post-hoc tests. Table 3.4 shows the ANOVA multiple comparisons.

Table 3.3. Tests of between subjects Effects

\begin{tabular}{|c|c|c|c|c|c|c|c|c|c|}
\hline \begin{tabular}{l|} 
Sourc \\
e
\end{tabular} & $\begin{array}{l}\text { Dependent } \\
\text { Variable }\end{array}$ & Type III & df & $\begin{array}{l}\text { Mean } \\
\text { Square }\end{array}$ & $\mathbf{F}$ & Sig. & Partial & $\begin{array}{c}\text { Noncent } \\
\text {. }\end{array}$ & $\begin{array}{c}\text { Observe } \\
\text { d }\end{array}$ \\
\hline & & Sum of & & & & & Eta & $\begin{array}{c}\text { Parame } \\
t\end{array}$ & Powerb \\
\hline & & Squares & & & & & $\begin{array}{c}\text { Square } \\
\text { d }\end{array}$ & er & \\
\hline $\begin{array}{l}\text { Correc } \\
\text { ted }\end{array}$ & $\begin{array}{l}\text { Tensile strength } \\
(\mathrm{MPa})\end{array}$ & $\begin{array}{c}61474.19 \\
5 \\
\end{array}$ & 2 & 30737.097 & . & & 1 & . & - \\
\hline \multirow[t]{7}{*}{ Model } & & $\mathrm{a}$ & & & & & & & \\
\hline & Elongation (\%) & $2.351 \mathrm{a}$ & 2 & 1.176 & . & . & 1 & . & . \\
\hline & $\begin{array}{l}\text { Fibre Density } \\
\left(\mathrm{g} / \mathrm{mm}^{3}\right)\end{array}$ & $387.331 \mathrm{a}$ & 2 & 193.665 & . & $\cdot$ & 1 & . & . \\
\hline & $\begin{array}{l}\text { Fibre Diameter } \\
(\mathrm{mm})\end{array}$ & $.110 \mathrm{c}$ & 2 & 0.055 & 76.34 & 0 & 0.566 & 152.68 & 1 \\
\hline & $\begin{array}{l}\text { Moisture Regain } \\
(\%)\end{array}$ & $17.617 \mathrm{~d}$ & 2 & 8.808 & 8.917 & 0 & 0.132 & 17.835 & 0.97 \\
\hline & $\begin{array}{l}\text { Fibre length } \\
(\mathrm{mm})\end{array}$ & $91.127 \mathrm{e}$ & 2 & 45.564 & 5.524 & 0.005 & 0.086 & 11.047 & 0.845 \\
\hline & $\begin{array}{l}\text { Linear density } \\
\text { (tex) }\end{array}$ & $57.097 \mathrm{a}$ & 2 & 28.548 & . & . & 1 & . & - \\
\hline \multirow[t]{10}{*}{$\begin{array}{l}\text { Interce } \\
\mathrm{pt}\end{array}$} & $\begin{array}{l}\text { Tensile strength } \\
\text { (MPa) }\end{array}$ & $\begin{array}{c}128838.5 \\
3\end{array}$ & 1 & $\begin{array}{c}128838.53 \\
3\end{array}$ & . & . & 1 & . & . \\
\hline & & 3 & & & & & & & \\
\hline & Elongation (\%) & 14.247 & 1 & 14.247 & . & . & 1 & . & . \\
\hline & $\begin{array}{l}\text { Fibre Density } \\
\left(\mathrm{g} / \mathrm{mm}^{3}\right)\end{array}$ & 1619.205 & 1 & 1619.205 & . & . & 1 & . & . \\
\hline & $\begin{array}{l}\text { Fibre Diameter } \\
(\mathrm{mm})\end{array}$ & 4.253 & 1 & 4.253 & $\begin{array}{c}5.90 \mathrm{E} \\
+0\end{array}$ & 0 & 0.981 & \begin{tabular}{|c}
5895.32 \\
2
\end{tabular} & 1 \\
\hline & & & & & 3 & & & & \\
\hline & $\begin{array}{l}\text { Moisture Regain } \\
(\%)\end{array}$ & $\begin{array}{c}13670.91 \\
8\end{array}$ & 1 & 13670.918 & $\begin{array}{c}1.38 \mathrm{E} \\
+0\end{array}$ & 0 & 0.992 & $\begin{array}{c}13840.0 \\
9\end{array}$ & 1 \\
\hline & & & & & 4 & & & 6 & \\
\hline & $\begin{array}{l}\text { Fibre length } \\
(\mathrm{mm})\end{array}$ & 7594.639 & 1 & 7594.639 & $\begin{array}{c}920.70 \\
4\end{array}$ & 0 & 0.887 & 920.704 & 1 \\
\hline & $\begin{array}{l}\text { Linear density } \\
\text { (tex) }\end{array}$ & 1329.336 & 1 & 1329.336 & . & . & 1 & . & . \\
\hline \multirow[t]{5}{*}{$\begin{array}{l}\text { Locati } \\
\text { on }\end{array}$} & $\begin{array}{l}\text { Tensile strength } \\
(\mathrm{MPa})\end{array}$ & $\begin{array}{c}61474.19 \\
5 \\
\end{array}$ & 2 & 30737.097 & . & . & 1 & . & . \\
\hline & Elongation (\%) & 2.351 & 2 & 1.176 & . & . & 1 & . & . \\
\hline & $\begin{array}{l}\text { Fibre Density } \\
\left(\mathrm{g} / \mathrm{mm}^{3}\right)\end{array}$ & 387.331 & 2 & 193.665 & . & . & 1 & . & . \\
\hline & $\begin{array}{l}\text { Fibre Diameter } \\
(\mathrm{mm})\end{array}$ & 0.11 & 2 & 0.055 & 76.34 & 0 & 0.566 & 152.68 & 1 \\
\hline & Moisture Regain & 17.617 & 2 & 8.808 & 8.917 & 0 & 0.132 & 17.835 & 0.97 \\
\hline
\end{tabular}




\begin{tabular}{|c|c|c|c|c|c|c|c|c|c|}
\hline & $(\%)$ & & & & & & & & \\
\hline & $\begin{array}{l}\text { Fibre length } \\
(\mathrm{mm})\end{array}$ & 91.127 & 2 & 45.564 & 5.524 & 0.005 & 0.086 & 11.047 & 0.845 \\
\hline & $\begin{array}{l}\text { Linear density } \\
\text { (tex) }\end{array}$ & 57.097 & 2 & 28.548 & & . & 1 & & \\
\hline \multirow[t]{7}{*}{ Error } & $\begin{array}{l}\text { Tensile strength } \\
(\mathrm{MPa})\end{array}$ & 0 & 117 & 0 & & & & & \\
\hline & Elongation (\%) & 0 & 117 & 0 & & & & & \\
\hline & $\begin{array}{l}\text { Fibre Density } \\
\left(\mathrm{g} / \mathrm{mm}^{3}\right)\end{array}$ & 0 & 117 & 0 & & & & & \\
\hline & $\begin{array}{l}\text { Fibre Diameter } \\
(\mathrm{mm})\end{array}$ & 0.084 & 117 & 0.001 & & & & & \\
\hline & $\begin{array}{l}\text { Moisture Regain } \\
(\%)\end{array}$ & 115.57 & 117 & 0.988 & & & & & \\
\hline & $\begin{array}{l}\text { Fibre length } \\
(\mathrm{mm})\end{array}$ & 965.102 & 117 & 8.249 & & & & & \\
\hline & $\begin{array}{l}\text { Linear density } \\
\text { (tex) }\end{array}$ & 0 & 117 & 0 & & & & & \\
\hline \multirow[t]{8}{*}{ Total } & $\begin{array}{l}\text { Tensile strength } \\
(\mathrm{MPa})\end{array}$ & $\begin{array}{c}190312.7 \\
2\end{array}$ & 120 & & & & & & \\
\hline & & 8 & & & & & & & \\
\hline & Elongation (\%) & 16.598 & 120 & & & & & & \\
\hline & $\begin{array}{l}\text { Fibre Density } \\
\left(\mathrm{g} / \mathrm{mm}^{3}\right)\end{array}$ & 2006.536 & 120 & & & & & & \\
\hline & $\begin{array}{l}\text { Fibre Diameter } \\
(\mathrm{mm})\end{array}$ & 4.447 & 120 & & & & & & \\
\hline & $\begin{array}{l}\text { Moisture Regain } \\
(\%)\end{array}$ & $\begin{array}{c}13804.10 \\
4 \\
\end{array}$ & 120 & & & & & & \\
\hline & $\begin{array}{l}\text { Fibre length } \\
(\mathrm{mm})\end{array}$ & 8650.868 & 120 & & & & & & \\
\hline & $\begin{array}{l}\text { Linear density } \\
\text { (tex) }\end{array}$ & 1386.433 & 120 & & & & & & \\
\hline $\begin{array}{l}\text { Correc } \\
\text { ted }\end{array}$ & $\begin{array}{l}\text { Tensile strength } \\
(\mathrm{MPa})\end{array}$ & $\begin{array}{c}61474.19 \\
5 \\
\end{array}$ & 119 & & & & & & \\
\hline \multirow[t]{6}{*}{ Total } & Elongation (\%) & 2.351 & 119 & & & & & & \\
\hline & $\begin{array}{l}\text { Fibre Density } \\
\left(\mathrm{g} / \mathrm{mm}^{3}\right)\end{array}$ & 387.331 & 119 & & & & & & \\
\hline & $\begin{array}{l}\text { Fibre Diameter } \\
(\mathrm{mm})\end{array}$ & 0.195 & 119 & & & & & & \\
\hline & $\begin{array}{l}\text { Moisture Regain } \\
(\%)\end{array}$ & 133.187 & 119 & & & & & & \\
\hline & $\begin{array}{l}\text { Fibre length } \\
(\mathrm{mm})\end{array}$ & 1056.229 & 119 & & & & & & \\
\hline & $\begin{array}{l}\text { Linear density } \\
\text { (tex) }\end{array}$ & 57.097 & 119 & & & & & & \\
\hline
\end{tabular}

\section{$R$ Squared $=1.000$ (Adjusted $R$ Squared $=1.000)$ \\ a. Computed using alpha $=.05$ \\ d. $R$ Squared $=.566($ Adjusted $R$ Squared $=.559) R$ Squared $=.132($ Adjusted $R$ Squared $=.117)$ \\ e. $R$ Squared $=.086$ (Adjusted $R$ Squared $=.071$ )}

Table 3.4 shows that fibre diameter was statically significantly different between middle and top (p < $.0005)$, and middle and root $(\mathrm{p}<.0005)$, root and middle $(\mathrm{p}<.005)$, root and top $(\mathrm{p}<.0005)$. Moisture regain was not statistically significant between middle and top $(\mathrm{P}=0.086)$, between root and top $(\mathrm{p}=0.098)$ but was statistically significant between middle and root $(\mathrm{p}<.005)$. Fibre length was not statistically significantly different between middle section and root section $(\mathrm{p}=0.279)$, between middle and top $(\mathrm{p}=0.178)$. Was statistically significant between root and top $(\mathrm{p}<.005)$. The variation in fibre length was significant between root and top section due to the fact that fibres were more compactly held on the root section and during 
extraction would break easily. Whereas on the top section the fibres were easy to remove with minimum breakages giving long fibres. This parameter can also affect critical length required in fabrication of different types of composites.

Table 3.4. ANOVA multiple comparisons

\begin{tabular}{|c|c|c|c|c|c|c|c|c|}
\hline Dependent & & $(\mathbf{I})$ & $(J)$ & Mean & Std. & Sig. & 95\% & \\
\hline Variable & & Locatio & Locatio & Differenc & Error & & Confidenc & Upper \\
\hline & & n on & n on & e (I-J) & & & e Interval & Boun \\
\hline & & stalk & stalk & & & & Lower & d \\
\hline & & & & & & & Bound & \\
\hline & & & & & & & & \\
\hline Fibre & Tuke & Mid & Roo & $-.0440^{*}$ & 0.0060 & 0 & -0.0583 & - \\
\hline Diameter & y & & & & 1 & & & 0.0297 \\
\hline
\end{tabular}

\begin{tabular}{|c|c|c|c|c|c|c|c|c|}
\hline & & & Top & $.0297 *$ & 0.0060 & 0 & 0.0155 & 0.044 \\
\hline & & & & & 1 & & & \\
\hline & & Roo & Mid & $.0440 *$ & 0.0060 & 0 & 0.0297 & 0.0583 \\
\hline & & & & & 1 & & & \\
\hline & & & Top & $.0738^{*}$ & 0.0060 & 0 & 0.0595 & 0.088 \\
\hline & & & & & 1 & & & \\
\hline & & Top & Mid & $-.0297 *$ & 0.0060 & 0 & -0.044 & - \\
\hline & & & & & 1 & & & 0.0155 \\
\hline & & & Roo & $-.0738 *$ & 0.0060 & 0 & -0.088 & - \\
\hline \multirow[t]{2}{*}{ Moisture } & & & & & 1 & & & 0.0595 \\
\hline & Tuke & Mid & Roo & $-.9385^{*}$ & 0.2222 & 0 & -1.4661 & - \\
\hline \multirow[t]{10}{*}{ Regain (\%) } & $\mathrm{y}$ & & & & 4 & & & 0.4109 \\
\hline & HSD & & \multirow[t]{2}{*}{ Top } & \multirow[t]{2}{*}{-0.4761} & 0.2222 & 0.08 & -1.0037 & 0.0515 \\
\hline & & & & & 4 & 6 & & \\
\hline & & Roo & Mid & $.9385^{*}$ & 0.2222 & 0 & 0.4109 & 1.4661 \\
\hline & & & & & 4 & & & \\
\hline & & & Top & 0.4624 & 0.2222 & 0.09 & -0.0652 & 0.99 \\
\hline & & & & & 4 & 8 & & \\
\hline & & Top & Mid & 0.4761 & 0.2222 & 0.08 & -0.0515 & 1.0037 \\
\hline & & & & & 4 & 6 & & \\
\hline & & & Roo & -0.4624 & 0.2222 & 0.09 & -0.99 & 0.0652 \\
\hline \multirow{2}{*}{$\begin{array}{l}\text { Fibre } \\
\text { length }\end{array}$} & & & & & 4 & 8 & & \\
\hline & Tuke & Mid & Roo & 0.985 & 0.6422 & 0.27 & -0.5396 & 2.5096 \\
\hline \multirow[t]{11}{*}{$(\mathbf{m m})$} & $\mathrm{y}$ & & & & 1 & 9 & & \\
\hline & HSD & & \multirow[t]{2}{*}{ Top } & -1.1475 & 0.6422 & 0.17 & -2.6721 & 0.3771 \\
\hline & & & & & 1 & 8 & & \\
\hline & & Roo & Mid & -0.985 & 0.6422 & 0.27 & -2.5096 & 0.5396 \\
\hline & & & & & 1 & 9 & & \\
\hline & & & Top & $-2.1325^{*}$ & 0.6422 & 0.00 & -3.6571 & - \\
\hline & & & & & 1 & 3 & & 0.6079 \\
\hline & & Top & Mid & 1.1475 & 0.6422 & 0.17 & -0.3771 & 2.6721 \\
\hline & & & & & 1 & 8 & & \\
\hline & & & Roo & $2.1325 *$ & 0.6422 & 0.00 & 0.6079 & 3.6571 \\
\hline & & & & & 1 & 3 & & \\
\hline
\end{tabular}

Based on observed means. The error term is Mean Square (Error) $=.000$

*. The mean difference is significant at the .05 level.

* Top - Top section of cotton stalk

* id-Middle section of cotton stalk

* Roo-Root section of cotton stalk

\section{CONCLUSION}


The cotton stalk fibres exhibited characteristics that made them suitable for use in different composite applications. The fibres from the root section showed overall statistically significant variation in terms of their tensile strength compared to fibres from the middle section and top section. With the root section fibres having tensile strength of $2.21 \mathrm{cNtex}$ compared to middle section fibres which had tensile strength of $56.3 \mathrm{cNtex}$ and top section fibres of $39.79 \mathrm{cN} /$ tex. There was statistical significant variation in fibre diameter of middle and top fibres, middle and root fibres as well as root and top fibres. There was no statistically significant variation in the following properties moisture regain, fibre length between fibres in the top section and middle section but there was statistically significant variation between middle section and root section as well as top section and root section fibres.. The fibres from the middle section showed the best overall mechanical properties followed by fibres from the top section. The fibres from the root section had poor tenacity. Further study needs to be carried out to study the chemical morphology of the fibres to better understand the underlining reason for the statistical variation in the properties of the fibres from different sections of the cotton stalk.

\section{ACKNOWLEDGEMENTS}

The author would like to appreciate sponsorship supplied by the European Union through the Metega programme that enabled this study to be possible.

\section{REFERENCES}

[1] N Reddy and Y Yang, Properties and potential applications of natural cellulose fibers from the bark of cotton stalks, Journal of Bioresource Technology, 100(14), 2009, 3563-3569.

[2] A.J.Shaikh, R.M.Gurjar, P.G Patil, K.M. Paralikar, Particle Boards from cotton stalk. Central Institute for Research on Cotton Technology, Mumbai, India, 2010

[3] M.Vinobaba, M. a, Efficacy of some selected botanical extracts against the Cotton mealybug Phenacocuccus solenopsis (Tinsley) (Hemiptera: Pseudococcidae). International Journal of Scientific and Researrch Publications, 1(3), 2014, 42250-3153.

[4] C.A. Silva, Occurrence of new species of mealybug on cotton fields in the States of Bahia and Paraiba, Brazil. Bragantia Campinas, 71(4), 2012, 467-470.

[5] K Hake, L Carter, L Moore, R Parker, R Summy, T Watson and R Willford, Cotton Stalk Management. Newslatter of the Cotton Physiology Education Program, 2(10), 1991, 1 -4.

[6] Y Copur, C Guler, M Akgul and C Tascioglu, Some chemical properties of hazelnut husk and its suitability for particleboard production, Building and Environment, 2006, 2568-2572

[7] A.Yzombard, S. G.Gordon and M.Miao, Morphology and tensile properties of bast fibres extracted from cotton stalks. Textile Research Jounal, 84(3) 2014, 303-311

[8] G Cao, X Zhang, Y Wang, F Zheng, Estimation of emissions from field burning of crop straw in China, Science Bulletin. 53(5), 2008, 784-790.

[9] M Hughes, Fibres for biocomposites. Aalto University, 2015

[10] M Eriksen and B.E Pallesen, New generation airforming for flax and hemp. Nonwovens World, 2002 , 80-84.

[11] S.Kalia and B. Kaith, Cellulose Fibers: Bio- and Nano-Polymer (New York: Springer, 2011).

[12] G.C Mohan Kumar, A study of short areca fiber reinforced PF composites, Proceedings of the world congress on engineering, London, UK 2008, 978-988

[13] J Holbery, D.Houston, Natural fibre reinforced polymer composites in automotive applications, Jounal of the minerals, metals and materials society, 2006, 80-86

[14] Miao, A Yzombaer and S Grdon, Bast fibres extracted from cotton stalks as reinforcement for polymer composites. Composites Australia Confrence, Gold Coast, Australia, 1-25, 2015

[15] N.Z.Nkomo, L.C.Nkiwane, D.Njuguna, E.N.Oyondi, Extraction and characterisation of the mechanical properties of cotton stalk bast fibres, Proceedings of the 2016 Annual Conference on Sustainable Research and Innovation, Nairobi, Kenya, 2016, 10-16

[16] ASTM-D5103-07, Standard test method for length and length distribution of manufactured staple fibres (Single fiber test) Pennsylvania: ASTM International, 2012, Retrieved from www.astm.org

[17] ASTM-D3822, Standard test method for tensile properties of single textile fibers. Pennsylvania: ASTM International, 2014, Retrieved from www.astm.org

[18] ASTM D629-15, Standard test method for quantitative analysis of textiles. Pennsylvania: ASTM International, 2015 Retrieved from www.astm.org

[19] ASTM-D1577-07, Standard test method for linear density of textile fibers. Pennsylvania: ASTM International, 2012 Retrieved from www.astm.org

[20] H Sharma and C. Van Sumere, Enzyme treatment of flax, Genetic Engineering and Biotechnologist, 12(2), 1992, 19-23. 